\title{
Bidding Behavior in the SNB's Repo Auctions
}

Sébastien Kraenzlin and Martin Schlegel

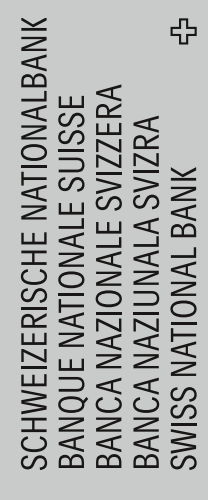


The views expressed in this paper are those of the author(s) and do not necessarily represent those of the Swiss National Bank. Working Papers describe research in progress. Their aim is to elicit comments and to further debate.

\section{Copyright $\odot$}

The Swiss National Bank (SNB) respects all third-party rights, in particular rights relating to works protected by copyright (information or data, wordings and depictions, to the extent that these are of an individual character). SNB publications containing a reference to a copyright ( $\odot$ Swiss National Bank/SNB, Zurich/year, or similar) may, under copyright law, only be used (reproduced, used via the internet, etc.) for non-commercial purposes and provided that the source is mentioned. Their use for commercial purposes is only permitted with the prior express consent of the SNB.

General information and data published without reference to a copyright may be used without mentioning the source.

To the extent that the information and data clearly derive from outside sources, the users of such information and data are obliged to respect any existing copyrights and to obtain the right of use from the relevant outside source themselves.

\section{Limitation of liability}

The SNB accepts no responsibility for any information it provides. Under no circumstances will it accept any liability for losses or damage which may result from the use of such information. This limitation of liability applies, in particular, to the topicality, accuracy, validity and availability of the information.

ISSN 1660-7716 (printed version)

ISSN 1660-7724 (online version)

๑ 2009 by Swiss National Bank, Börsenstrasse 15, P.0. Box, CH-8022 Zurich 


\title{
Bidding Behavior in the SNB's Repo Auctions
}

\author{
Sébastien Kraenzlin and Martin Schlegel* \\ Swiss National Bank and University of Basel ${ }^{\dagger}$
}

October 2009

\begin{abstract}
The Swiss National Bank (SNB) provides reserves to market participants via fixed rate tender auctions. We analyze the banks' bidding behavior and identify the determinants for the decision to participate as well as on the amount to tender. Therefore, we estimate bidding functions for banks which participate regularly in the SNB's auctions. We find that a bank's bids from the previous day and the amount of maturing repo operations with the SNB have for most banks a significant effect. The autonomous factors (government balances at the SNB and currency in circulation) are of only minor importance. A further determinant of the bidding behavior is the attractiveness of the SNB's auction rate compared to the prevailing interbank market repo rate. The spread of unsecured and repo rates as well as the attractiveness of funding Euros indirectly via a Swiss franc repo transaction with the SNB are only for few banks significant. Further, the question is addressed whether the bidding behavior changed in the financial market crisis of $2007 / 2008$. There is little evidence of a systematic change in bidding behavior in the crisis. This results from the fact that the SNB has addressed the volatile demand for reserves in the crisis with overnight fine-tuning operations.
\end{abstract}

Keywords: Open Market Operations, Bidding Behavior, Fixed Rate Tender Auction, Repo, Switzerland

JEL-Codes: D44, E52, E58

\footnotetext{
${ }^{*}$ Swiss National Bank (Money Market and Foreign Exchange) and University of Basel (Department of Economics, WWZ). E-Mail: Martin.Schlegel@snb.ch and Sebastien.Kraenzlin@snb.ch

${ }^{\dagger}$ The authors contributed equally to this publication. The content of the publication is the sole responsibility of the authors and does not necessarily reflect the views of the Swiss National Bank. We gratefully acknowledge helpful comments from Nicole Braendle, Karl Hug, Caesar Lack, Peter Kugler, Thomas Jordan, Ernst Lienhard, Dewet Moser, Patrick Roesli, Lidia Schmidt, Sandra Strametz. The authors also thank the anonymous referee for valuable comments and suggestions.

Received: July 2009; and accepted in revised form in October 2009.
} 


\section{Introduction}

As Switzerland's central bank the Swiss National Bank (SNB) is mandated by the constitution to conduct Switzerland's monetary policy. The SNB's monetary policy framework consists of three elements. The first element is a definition of price stability: The SNB defines price stability as a rise in the national consumer price index (CPI) of less than $2 \%$ p.a. The second element is an inflation forecast. Since the transmission of monetary policy to the economy exhibits lags, the inflation forecast covers three years. The third element is a target range for the Swiss franc 3-month Libor, serving as operational target. To manage the 3-month Libor, the SNB transacts with financial market participants. For a detailed description of the SNB's monetary policy framework see SNB (1999).

The SNB's main instrument to manage the 3-month Libor are daily repo transactions. Through repo operations the SNB provides reserves to the banking system (sight deposits at the SNB). To guarantee an equal treatment of all counterparties, the SNB conducts its daily 1-week repo transactions in the form of an auction. It thereby uses a fixed rate tender. The SNB announces the conditions of the repo transaction (repo rate and term). The counterparties submit their bids. Each counterparty submits the amount for which it is willing to accept reserves at the given repo rate. If the total amount of all bids exceeds the SNB's planned allotment, it allocates the reserves proportionally to the counterparty's bid (see SNB (2008)). Since banks usually anticipate the proportional cut of their bid, they incorporate this expectation when assessing the amount to tender.

The aim of this paper is to shed light on banks' decision to participate in the 1-week repo auction and on the determinants of the bid amount. Based on individual bidding data from 29 banks that participated regularly in the SNB's auctions we estimate two bid functions per bank. The first bid function models a bank's decision to take part in the auction and the second estimates the bank's bid amount. These functions help to better understand demand in the SNB's liquidity providing operations. This is of special interest as the SNB grants access to a wide range of counterparties, comprising banks domiciled in Switzerland but also banks domiciled abroad.

The sample ranges from January 2004 to September 2008. Hence, it covers the first part of the money market turmoil that started in August 2007. The period since October 2008 is not included, since the SNB has employed a wider range of instruments in that time. Other central banks provided Swiss francs to their counterparties too. We cannot observe if banks participating in the SNB's auction also participated in another central bank's operations. Due to uncertainties about the severity of the crisis, banks became suddenly very risk averse. Accordingly, they were reluctant 
to lend funds on an unsecured basis and for terms longer than a few days. As in other major currencies, the risk premium rose sharply in the Swiss franc money market reflecting the higher perception of credit and liquidity risk (see CGFS (2008)). This rendered it more difficult for banks with a refinancing need to raise the necessary funds. We therefore also examine if the banks' bidding behavior changed in the crisis.

We find that the factors affecting reserves (e.g. yesterday's bids and a bank's maturing repo operations) exhibit a strong influence on the decision to participate in the auction and on the bid amount. From the set of interest rate factors the relative attractiveness of the SNB's rate to the interbank repo rate is the most relevant factor. Similar evidence was found by Breitung/Nautz (2001), Nautz/Oechssler (2006) and Linzert et al. (2006) suggesting that banks are more likely to participate or bid higher volumes in the Eurosystem's auction when central bank reserves are cheaper than in the interbank market. The variable capturing the attractiveness of FX-swaps is only of minor relevance. This finding suggests that banks do not primarily use the SNB's auction to fund Euros, by obtaining the Swiss francs via repo transaction and subsequently swapping these Swiss francs into Euros via an FX-swap. The fulfillment of minimum reserve requirements is irrelevant for the bidding behavior of a large part of the banks under consideration. This was also found by Linzert et al. (2006). Finally, we show that the banks' bidding behavior did not systematically and materially change in the recent money market turmoil. The reason for the unchanged behavior lies primarily in the fact that the SNB conducted fine-tuning operations to accommodate the volatile demand for reserves. The fine-tuning operations are usually conducted in the overnight tenor, meaning they have an immediate effect on a bank's reserves and hence on overnight rates. Because of these fine-tuning operations, bidding behavior in the 1-week auction was not substantially affected. Eisenschmidt et al. (2009) analyse banks bidding behaviour in the ECB's main refinancing operations during the financial turmoil in money and financial markets. They find that increased bid rates during the turmoil can be explained, among other factors, by the increased attractiveness of the ECB's tender operations due to its collateral framework and banks bidding more aggressively to avoid being rationed at the marginal rate in times of increased liquidity uncertainty.

The paper is structured as follows. The next section provides a short overview of the SNB's framework for the implementation of monetary policy. Section 3 describes the banks' determinants to participate and bid in the auction. In the subsequent section the data is described. Section 5 presents the bid functions and interprets the empirical findings. Section 6 concludes. 


\section{Implementation of monetary policy at the SNB}

This section provides a brief overview of the SNB's implementation of monetary policy. Since January 2000 the SNB announces a target range for the Swiss franc 3-month Libor as operational target for the implementation of monetary policy. The width of the target range is usually 1 percentage point. The SNB communicates to the public the aimed level of the 3-month Libor within the target range, which is usually the "middle of the target range". Since a 3-month rate depends on expectations of shorter term rates, the SNB allows fluctuations of the Libor within the target range. This tolerance of fluctuations gives the SNB the leeway to react to other variables - like the risk premium in money market or movements in the exchange rate - without altering its formal monetary policy stance (see also Baltensperger et al. (2007)).

The management of the Swiss franc 3-month Libor is done through several channels. Firstly, the announcement of the target range itself has an influence on the Libor. Secondly, since the Libor depends on expectations, the governing board manages the market expectation of future monetary policy actions. This is mainly done by giving speeches and interviews. The third element are the SNB's open market operations, which we describe in detail in section 2.1 .

The level of reserves of domestic banks with the SNB is mainly determined by minimum reserve requirements: Banks have to hold a certain percentage of their short term liabilities and savings deposits in form of reserves with the SNB and/or vault cash. The minimum reserve requirements have to be fulfilled on average over the course of a maintenance period, which runs from the $20^{t h}$ of every month to the $19^{\text {th }}$ of the following month.

The Swiss National Bank Act states that one of the SNB's tasks is to supply the Swiss franc money market with reserves. In the sample period the Swiss banking system is in a structural liquidity deficit. A structural liquidity deficit is a situation where the banking system is short of reserves versus the central bank, i.e. banks have to recur regularly to refinancing from the central bank. The structural liquidity deficit is evident from the position sight deposits of domestic banks and claims from repo transactions in the SNB's balance sheet. The claims from repo transactions (roughly 20 bn Swiss francs) on the asset side of the SNB's balance sheet exceed the banks' sight deposits (roughly 5 bn Swiss francs) on the liabilities side. So the banking system owes the central bank more than it claims. The reserves to cover this deficit are provided by the SNB to the banking system through open market operations.

With respect to the implementation of monetary policy, there are basically two types of banks. The first type exhibits excess reserves, meaning 
that it is a net lender of reserves to other banks. This type of banks mainly consists of banks collecting deposits from non-banks without sufficient possibilities to invest the received funds. The second type exhibits a reserve deficit, meaning it is a net borrower of reserves. This type of banks can cover its refinancing need either in the interbank market or from the SNB. Note that a bank can change its type once in a while. If a bank participates in the SNB's reserves providing operations, it is usually of type two.

\subsection{Open Market Operations}

There are two types of open market operations that the SNB employs to supply the Swiss franc money market with reserves: Daily auctions usually at 9.00 am and fine-tuning operations. Auctions are conducted by way of a fixed rate tender (volume tender). In a fixed rate tender auction, the SNB announces the interest rate and term it offers to its counterparties. The targeted allotment in the auction is not communicated to the public. Banks then have 10 minutes to tender their bids, without knowing the bids of the other banks. After closing the auction, the SNB starts the allotment process. If total bids exceed the SNB's targeted allotment, each bank's bid is proportionally reduced. The interest rate, the allotment and the term offered depend on the SNB's specific monetary policy intentions. In particular, the SNB sets the term of the transactions in such a way that the banks have to request reserves on an almost daily basis. The high frequency of auctions facilitates liquidity management for the SNB and the participating banks, and gives the SNB the opportunity to respond quickly to a change in market conditions and to influence interest rates in the desired manner (see SNB (2004)).

The aim of fine-tuning operations is to counter undesired fluctuations in short term interest rates. These can be caused by a shift in the banks' demand for reserves and by unexpected movements of reserves due to fluctuations in autonomous factors. The autonomous factors comprise the government's balances with the SNB and currency in circulation, which are both forecasted by the SNB when determining the target allotment. Finetuning operations are conducted by placing quotes or (seldom) by accepting the banks' quotes in the repo interbank market. Fine-tuning operations are conducted only intermittently.

A further type of regular open market operation is the issue of central bank bills, so-called SNB Bills. SNB Bills were introduced in October 2008 to absorb reserves provided via EURCHF FX-swaps. The FX-swaps are a coordinated measure of the SNB with the European Central Bank (ECB) and the central banks of Poland and Hungary. Since the sample period in 
this paper ranges from January 2004 to September 2008 these instruments are not covered in this paper.

\section{$2.2 \quad$ Standing Facilities}

In its standing facilities, the SNB sets the conditions under which banks can obtain short-term reserves. The SNB has two sorts of standing facilities: The liquidity-shortage financing facility and the intraday liquidity facility. The purpose of the liquidity-shortage financing facility is to bridge shortterm liquidity bottlenecks. To draw from the liquidity-shortage financing facility, a bank needs a limit that defines the maximum amount of reserves that can be drawn. This limit has to be covered with at least $110 \%$ collateral eligible for SNB repos at all times. In the period of observation the interest rate for this facility is set 200 basis points above the repo-overnight-index (SNB) of the previous day. ${ }^{1}$ This penalty rate was chosen to deter banks from regularly recurring to this facility and to increase the incentives for an accurate liquidity management.

The aim of the intraday facility is to grease the payment system. To avoid gridlocks and allow banks to cheaply settle their payment transactions early in a value day, banks can draw funds from the intraday facility. This liquidity has to be repaid by the end of the value day. Since intraday liquidity is a public good and has no implications for monetary policy, it is provided to banks on an interest rate free basis.

\subsection{Counterparties}

Eligible counterparties in the SNB's open market operations are granted access to all facilities. With regard to the eligibility of counterparties, the SNB pursues an open access policy. ${ }^{2}$ This means, that the SNB does not discriminate between original domiciles of banks or the legislation to which they are subject. As a result, on average $40 \%$ of the SNB's counterparties are domiciled abroad and participate frequently in the auctions. Most other central banks are more restrictive in this respect. ${ }^{3}$ The advantage of granting access to a broad range of counterparties is a more effective distribution

\footnotetext{
${ }^{1}$ With effect from 1 January 2009 the premium on the interest rate was reduced from previously 200 basis points to 50 basis points.

${ }^{2}$ In general, a central bank can grant access to its facilities to four different types of bank groups: (i) Primary dealers which represent a selection of domestic banks or securities broker-dealers; (ii) domestic banks; (iii) branches and subsidiaries which are owned by banks domiciled abroad but regulated by the host country and (iv) banks domiciled abroad. The SNB grants access to all types of bank groups.

${ }^{3}$ The Federal Reserve, for example, only grants access to open market operations to a selected circle of banks (primary dealers), while all institutions that are subject to the Eurosystem's minimum reserve system have access to the ECB's facilities. Hence, to
} 
of central bank reserves and hence a more direct monetary policy implementation. Unnecessary interdependencies in the distribution of reserves and bypassing operations can be prevented. Furthermore, interbank market strains - especially in times of market stress - can be addressed more effectively.

obtain the necessary reserves, a bank domiciled abroad has to establish a branch in the relevant country or participate in the respective interbank market. 


\section{Bid functions}

\subsection{Influencing factors}

This section identifies the relevant factors for the banks' bidding behavior in the SNB's 1-week auctions. The diversity of eligible counterparties implies that banks have different motives to participate in the auction. The decision on participation and on the amount to tender will therefore depend on the existence and magnitude of the various influencing factors for a bank. These influencing factors can be categorized into factors affecting reserves (liquidity factors) and interest rate factors. These factors are subsequently outlined.

\section{Liquidity factors}

The first factor is a bank's bid in the auction of the previous working day $B_{i, t-1}$. There are two antagonizing factors that yesterday's bids exert. On the one hand, there is a saturation effect. Higher bids of a bank on the previous day - and hence a higher individual allotment - reduce the probability for a bank to recur to the SNB's auction the day after, because its demand for reserves in the next six days has been satisfied to a higher extent. This would lead to a negative relationship between yesterday's and today's bids. On the other hand, there is a refinancing position effect. A bank's decision to participate in the auction depends on its momentary (mediumterm) refinancing need. If it has a refinancing need, it will recur regularly to the auction and refrain from participation if it has excess reserves. This effect would lead to a positive relationship between yesterday's and today's bids.

The second factor is the amount of a bank's maturing repo operations. By incorporating the maturing operations $\left(M O_{i, t}\right)$ into the regression, we capture a bank's recurrence to the SNB's financing operations as it wants to roll over its repos with the SNB to cover its short position. The maturing operations are measured as the amount of a bank's reserves - irrespective of its original term - maturing on the value day of the specific 1-week auction.

The SNB provides on average 4 bn Swiss francs per working day to its counterparties in five 1-week auctions per week, amounting to approximately 20 bn Swiss franc in outstanding repo operations. If the SNB provides longer-term repos, demand for 1-week repos from a bank which has participated in the longer term operation should - ceteris paribus - decrease. The 1-week and longer term repos are close substitutes for banks. A higher amount of longer-term repos outstanding is expected to be negatively linked with a banks' decision to participate in the SNB's auction as well as on the amount to tender. In this paper, longer term repos are measured by a bank's outstanding volume from repo transactions with a term of more than one week $\left(L T_{i, t}\right)$. 
Another influencing factor is a bank's fulfillment of the minimum reserve requirements. Domestic banks and Swiss branches of banks domiciled abroad have to fulfill minimum reserve requirements. ${ }^{4}$ In addition, branches of foreign banks that may not necessarily need a bank license due to treaties with other states have to meet these requirements. ${ }^{5}$ Hence, these banks participate also in the SNB's auctions to fulfill their minimum reserve requirements. The degree of fulfillment of minimum reserve requirements is approximated by the quota $\left(M R_{i, t}\right)$ of the current average of reserves in the maintenance period and the average level of reserves at the end of the respective period. ${ }^{6}$ A quota below (above) 100 stands for the fact that the bank is momentarily holding less (more) reserves than it wants to hold on average in the maintenance period. It should thus have a higher (lower) incentive to participate in the auction and bid more (less) aggressively.

A further liquidity factor are the banknotes in circulation $B N_{t}$. Banknotes in circulation are a close substitute for reserves. If a bank needs banknotes to fill automated teller machines (ATM), it withdraws banknotes from its reserve account with the central bank. An increase in banknotes in circulation will lower reserves. Higher banknotes in circulation should thus provide an incentive for banks to participate in the SNB's auction and to bid more aggressively.

The last liquidity factor are the government's balances with the SNB. The SNB provides banking services to the Swiss government. ${ }^{7}$ The government's balances $\left(G_{t}\right)$ with the central bank influence the banks' reserves. If the government's balances with the central bank increase - for example because of tax payments - the level of reserves decreases. Less reserves in the banking system is thus expected to be positively linked with the decision to participate in the SNB's auction as well as on the amount to tender.

\section{Interest rate factors}

The Swiss franc repo interbank market sets the same standards with respect to eligible collateral, its handling and settlement as the SNB. As a consequence this market and the prevalent rate figures as main influencing interest rate factor. If the SNB's repo rate is below the repo rate in the interbank market, it is attractive for a bank to tender in the auction instead of refinancing itself in the interbank market. When the SNB's repo rate is

\footnotetext{
${ }^{4}$ See National Bank Act arts. 17, 18 and 22-24, as well as the National Bank Ordinance arts. 12-17 for more information on minimum reserve requirements.

${ }^{5}$ Art. 2 of the Banking Law.

${ }^{6}$ This approximation assumes that the SNB exactly provides the demanded reserves (minimum reserve requirements plus excess liquidity) over the course of a maintenance period. This assumption is plausible, since a provision of more (less) reserves would lead to a undesired increase (decrease) in interest rates.

${ }^{7}$ Art. 5 para. 4 and art 11 of the National Bank Act.
} 
above the market rate, a bank may refrain from participating in the auction and borrow the money in the interbank repo market instead. In the regression in section 5 the interest rate difference between the SNB's repo rate and the respective market interest rate, i.e. $r_{r e p o, t}=r_{S N B, t}-r_{I B, t}$, is used as explanatory variable.

A majority of the SNB's counterparties are active in several currencies. A bank may have a refinancing need in one currency and excess funds in another currency. For a bank to participate in the auction it needs to have a refinancing need in at least one currency. On the one hand, banks with a refinancing need in Euros will recur to the SNB's auction if the funding of Euros via the SNB's Swiss franc auction and the subsequent FX-swap (Swiss franc against Euro) becomes relatively more attractive than a direct funding in the Euro repo market. These banks will bid more in the SNB's auction if the FX-swap variable increases. On the other hand, banks with an investment need in Euros - and a refinancing need in Swiss francs - will bid less if the rate obtained for Euros in the FX-swap is relatively more attractive than investing the funds in the Euro repo market (and obtaining the funds in the SNB's auction). Figure 1 illustrates this reasoning. We measure the relative attractiveness of the funding/investing via FX-swap with the SNB's rate, the Eurepo rate and the EURCHF-swap market rate. The FX-swap variable is denoted $F X_{t}$.

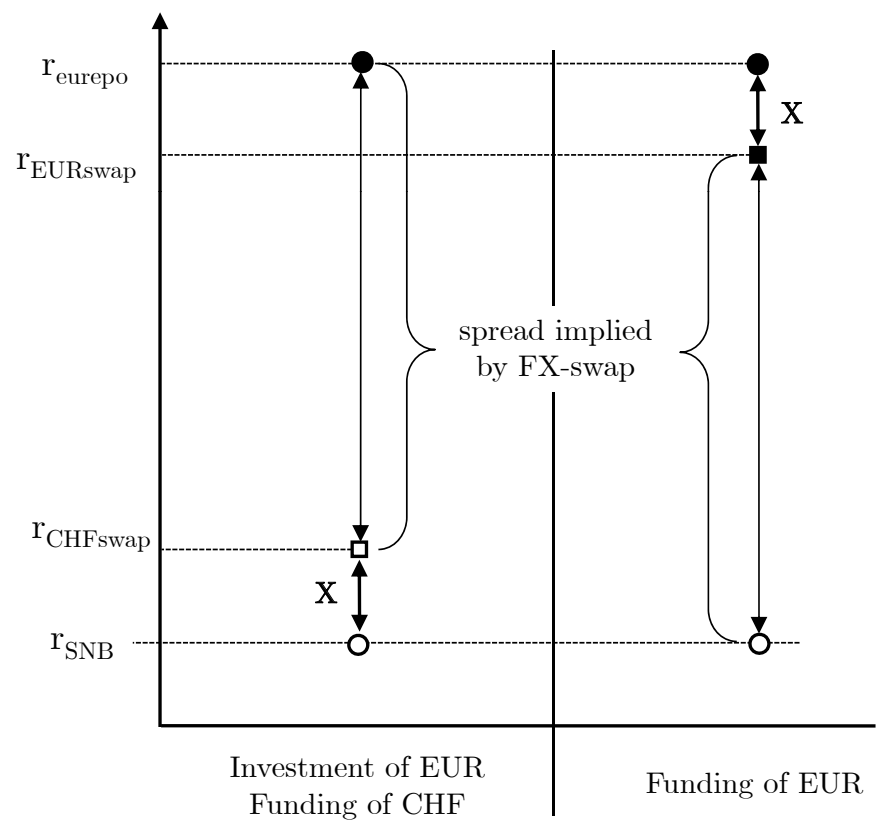

Figure 1: FX-swap: EUR funding vs. EUR investment/CHF funding

In times of market stress, uncertainty on refinancing conditions on the 
unsecured markets increases. This is reflected in a higher spread between the interest rates for unsecured and secured funds. Two motives link this spread with bidding behavior. Firstly, higher uncertainty regarding the capability of obtaining the funds on the unsecured interbank market should induce a bank to participate in the SNB's auction and to bid more aggressively. Secondly, a bank may find it profitable to obtain funds in the SNB's auctions and to lend them in the unsecured interbank market at a higher rate. However, a bank will only enter these trades if applied collateral costs and desired compensation for risk are lower than the spread between the unsecured rate and the SNB's repo rate. The variable is calculated as difference between the 1-week Libor and the SNB's 1-week repo rate $\left(r_{\text {unsec }, t}=l 1 W, t-r_{S N B, t}\right)$. This measure is often referred to as risk premium.

\subsection{Relationship between bid amount and true demand}

As mentioned in section 2.1, the SNB uses a fixed rate tender auction to provide reserves to the banking system. If the bids exceed the amount which the SNB wants to allot, they are cut proportionally. The possibility of a proportional cut may lead to strategic bidding behavior, which implies that the bid amount is - unless the banks expect a full allotment - a multiple of the amount that a bank actually wants to obtain, its true demand $D_{t r u e, i, t}$ (see Ehrhart (2000)). The SNB, contrary to the ECB, has been spared by a strategic bidding behavior leading to a steadily decreasing allotment ratio. ${ }^{8}$ This can be explained by the high frequency (daily) of auctions by the SNB, the SNB's adjustments of the allotment to demand and the same collateral standard as the interbank market. Daily auctions reduce a bank's risk of a permanent shortfall of refinancing, since a shortfall can be compensated on the next day. The adjustment of the allotment to demand increases the probability of obtaining too much reserves. This prevents a bank form bidding excessively in the auction. Finally, the same collateral standard as the interbank market allows a bank to easily finance a shortfall in the market. A bank's true demand depends on the factors described in section 3.1 , so

$$
\begin{gathered}
D_{\text {true }, i, t}=\mathbb{D}_{i}\left(B_{i, t-1}, M O_{i, t}, L T_{i, t}, M R_{i, t}, B N_{t}, G_{t}, r_{\text {repo }, t}, F X_{t}, r_{\text {unsec }, t}\right) \\
Q_{t} \equiv \frac{A_{t}}{B_{t}} \\
D_{\text {true }, i, t}=E\left(Q_{t}\right) \cdot B_{i, t} \rightarrow B_{i, t}=\mathbb{B}_{i}(\cdot)=\frac{\mathbb{D}_{i}(\cdot)}{E\left(Q_{t}\right)}
\end{gathered}
$$

\footnotetext{
${ }^{8}$ See Breitung/Nautz (2001) and Nautz/Oechssler (2006) for a review and discussion on the overbidding phenomenon in the ECB System.
} 


$$
\begin{gathered}
E\left(Q_{t}\right)=Q_{t-1}=\frac{A_{t-1}}{B_{t-1}} \\
B_{i, t}=\mathbb{B}_{i}(\cdot)=\frac{\mathbb{D}_{i}(\cdot)}{A_{t-1} / B_{t-1}}
\end{gathered}
$$




\section{The data}

This section provides a description of the data used in section 5. In principle, the SNB can conduct repo auctions with terms of 1 day to several months. There is no preannounced schedule for the SNB's Swiss franc repo auctions. However, the SNB almost invariably conducts repo auctions on a daily basis. The importance of the 1-week term for the SNB's open market operations varied during the years. While from 2000 to 2003 1-week repo auctions were used in $27 \%$ of the auctions, the SNB had used this term in approximately $90 \%$ of the cases since 2004. To analyze the banks' bidding behavior we will thus focus on the 1-week operations from January 2004 to September 2008. In the sample period 1,104 1-week auctions were conducted with an average of 18 banks participating. ${ }^{9}$ Of these 18 banks, an average of 9 were domiciled in Switzerland and 9 domiciled abroad.

As shown in figure 2 the total bids varied considerably. In the sample period the average bid amount was 24.6 bn Swiss francs. On average the SNB allotted roughly 4 bn Swiss francs. Table 1 provides a summary of the SNB's auctions for the pre-crisis period and the crisis. Total bids decreased on average during the crisis. Since the true demand is given by the bids multiplied by the expected allotment ratio (see section 3.2), the lower bids during the crisis do not imply a lower demand for reserves. They are rather an outcome of higher expected allotment ratios. The number of participating banks did not materially change in the crisis.

A selection of liquidity variables is depicted in figure 3 . The autonomous factors (government balances at the SNB and banknotes in circulation) are shown in aggregated form. Before the crisis, the SNB used longer term repo operations only occasionally. In this period, the longer term operations were generally not compensated by lower volumes in 1-week operations, i.e. the operations were not substitutes. As a consequence, the total outstanding repo volume rose when the SNB provided longer term repos. The increase in outstanding repo volume was mainly used to compensate increases in autonomous factors. In the crisis, on the contrary, longer term operations seem to be a substitute for shorter term operations. The total outstanding repo volume did not rise one-to-one with longer term repos: The main objective of using longer term repos instead of 1-week repos was to alleviate banks' liquidity position. Finally, the thick black line depicts the difference between the outstanding repo volume and the autonomous factors. This is a rough measure for the degree of the SNB's reserve provision. It is evident, that the provision of reserves was rather stable in the sample period.

Figure 4 shows a selection of interest rates used in the analysis. Since

\footnotetext{
${ }^{9}$ Figures refer to 1 -week auctions, where no other auction had taken place on the same day.
} 


\begin{tabular}{|c|c|c|c|c|c|c|c|c|}
\hline & \multicolumn{4}{|c|}{ Pre-crisis } & \multicolumn{4}{|l|}{ Crisis } \\
\hline & Mean & St.Dev. & Max & Min & Mean & St.Dev. & $\operatorname{Max}$ & Min \\
\hline Total bids & 28.2 & 20.1 & 178.6 & 0.9 & 20.0 & 17.0 & 114.0 & 0.6 \\
\hline Total allotment & 4.0 & 1.2 & 8.9 & 0.9 & 4.3 & 1.4 & 8.0 & 0.6 \\
\hline Longer term OMOs & 2.2 & 3.4 & 17.1 & 0.0 & 6.1 & 5.4 & 20.0 & 0.0 \\
\hline Minimum reserves & 101.2 & 11.4 & 187.1 & 53.8 & 95.0 & 17.3 & 128.1 & 41.2 \\
\hline Banknotes & 37.4 & 1.3 & 43.2 & 35.0 & 39.7 & 1.2 & 44.1 & 37.5 \\
\hline Government & 2.5 & 2.1 & 9.8 & 0.2 & 5.7 & 5.5 & 15.2 & 1.0 \\
\hline Spread repo & -0.01 & 0.02 & 0.07 & -0.19 & 0.00 & 0.03 & 0.13 & -0.11 \\
\hline Spread FX-swap & -0.04 & 0.07 & 0.76 & -0.27 & -0.12 & 0.16 & 0.81 & -0.80 \\
\hline Spread unsecured & 0.10 & 0.04 & 0.32 & -0.02 & 0.21 & 0.11 & 0.74 & -0.01 \\
\hline Nr. of bidders & 17.2 & 4.1 & 35.0 & 5.0 & 17.8 & 3.7 & 31.0 & 7.0 \\
\hline
\end{tabular}

bn Swiss francs, percentage points, number

Table 1: Descriptive stats of the variables

the 1-week Libor is an unsecured rate it lies above the 1-week interbank repo rate. The spread between the two rates varied only modestly prior to the crisis. In the crisis, this spread widened sharply and the Libor's volatility rose. This is due to a higher risk premium and/or a rise in collateral cost. The repo interbank rate and the SNB's rate are roughly equal. The spread amounts to $1 \mathrm{bp}$ prior to the crisis and to $0 \mathrm{bp}$ in the crisis. Nevertheless, the fluctuation of the interbank repo rate around the SNB's rate is higher in the crisis than before. The FX-swap variable (not depicted in the graph, but shown in table 1) is more negative in the crisis. This implies that the funding of Euros via Swiss franc repos with the SNB is more attractive than directly in the Euro repo market or accordingly the investment of Euros to obtain Swiss francs in a FX-swap less attractive than obtaining Swiss francs from the SNB. This reflects the relative scarcity of Swiss francs in the crisis. 


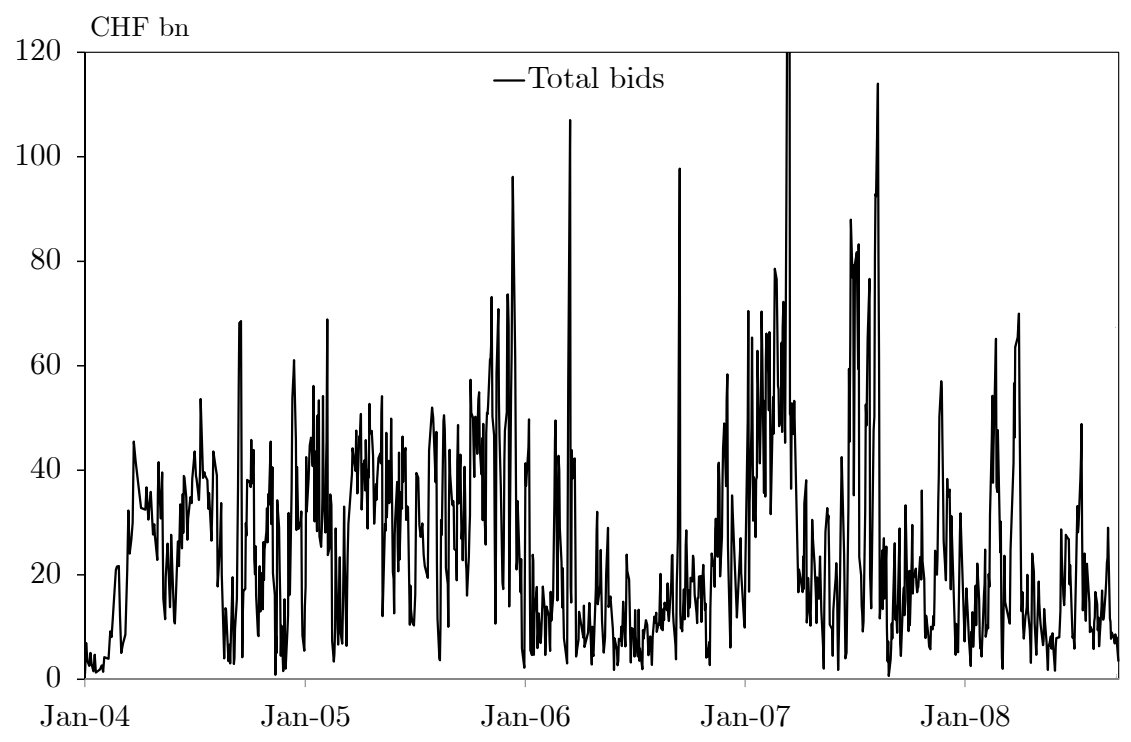

Figure 2: Total Bids in the SNB's 1-week auctions

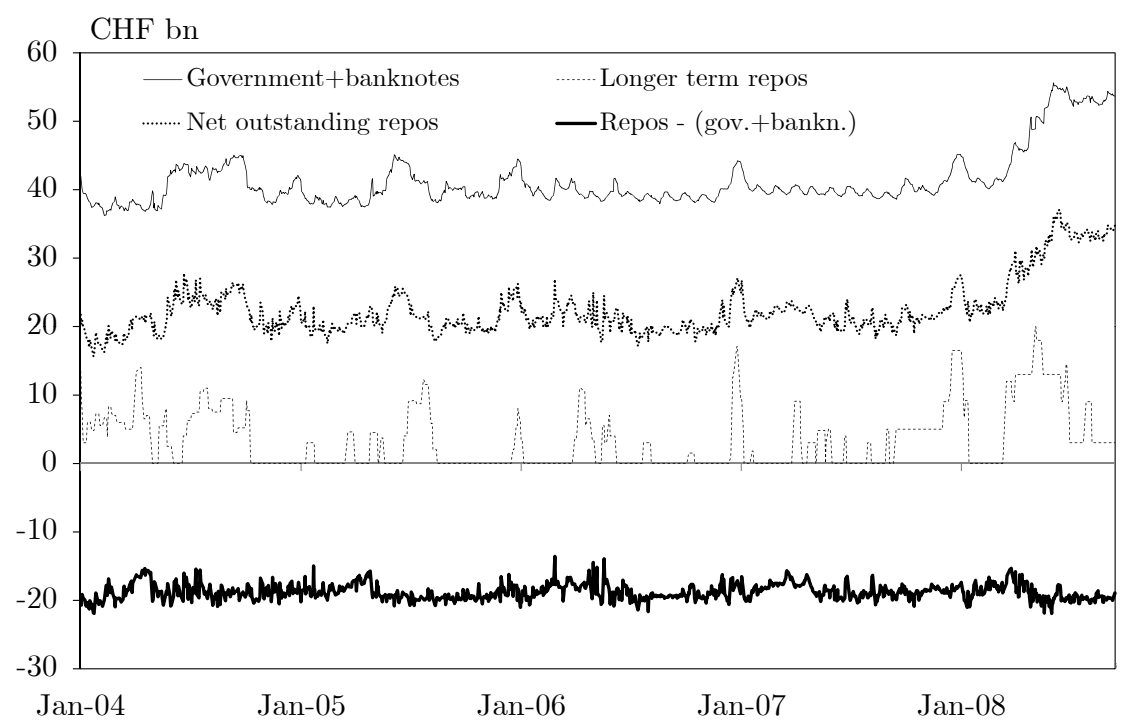

Figure 3: Overview of liquidity variables 


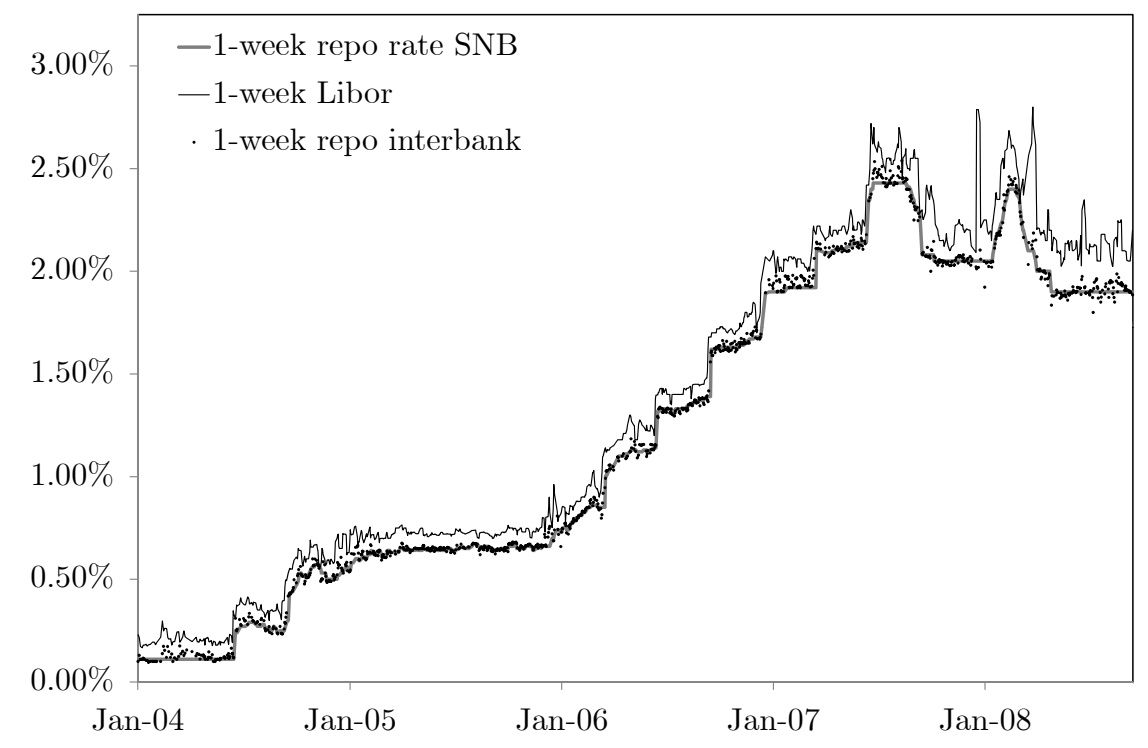

Figure 4: Interest rates 


\section{Results}

To shed light on the individual bank's motives to participate in the auction, we estimate a probit and tobit regression for 29 banks. These banks participated in the SNB's auctions both before and during the crisis. The 29 banks cover on average $77 \%$ of the number of banks participating and $89 \%$ of total bids. To address the question if the bidding behavior changed in the money market turmoil, we include the same set of regressors multiplied by a dummy variable, which takes the value 1 in the crisis (August 2007 to September 2008) and 0 before the crisis. The subsequent section investigates the impact of the various influencing factors on the decision to participate in the auction. Section 5.2 then examines banks' bid amount.

\subsection{Decision on participation}

We first examine the question which factors influence the banks' decision to participate in the auction on a given day. This question is analyzed by using a probit model, where the dependent variable $y_{i, t}$ equals 1 if bank $i$ participates in the auction on day $t=1, \ldots, T$ and 0 otherwise. The regression results are shown in table 4 . The 29 rows of the table correspond to the 29 banks, the 10 columns to the regressors. ${ }^{10}$

For 23 banks yesterday's own bid has a positive influence on the decision to participate in today's auction. This finding shows that the liquidity position effect outweighs the saturation effect. The highly significant and positive influence of the maturing repo operations for most banks is straightforward: A higher volume of maturing repo operations increases a bank's short position versus the SNB and consequently leads to a higher probability of participation. In the sample period, the probability to participate in the auction rose for eight banks if they had longer term repos outstanding with the SNB. Before the crisis, the SNB often used longer term repo operations to partially offset a shortage of reserves in the banking system due to an increase in the autonomous factors (banknotes and government's balances at the SNB). So, if a bank was strongly affected by the increase in the autonomous factors but did not fully cover its refinancing needs in the longer term auctions, it had to recur more often to the regular 1-week auctions. For three banks the probability of participation decreases the more longer term operations they have outstanding with the SNB. For these banks the longer term operations are substitutes for 1-week transactions. They cover their refinancing need in the longer term operations and accordingly it is less likely for them to take part in the 1-week auction. The majority of the significant coefficients on the banknotes in circulation and the government's balances at the SNB have not the expected sign. As an individual bank's

\footnotetext{
${ }^{10}$ For bank38 no probit regression was estimated as it participated in every auction.
} 
inflows and outflows resulting from banknotes and government balances are not observed, we use aggregate data. This may be a possible reason for the low explanatory power of the intuitively important variables. A further aspect is that both variables are not public information and difficult to forecast for a bank two days in advance. ${ }^{11}$ Provided that a bank holds less reserves than required on average, it should have a higher incentive to participate in the SNB's auction. As in Linzert et al. (2006) this is not substantiated by the data.

The influence of the interest rate factors (repo, FX-swaps and unsecured) on the decision to participate is mixed. The repo variable seems to be the most relevant determinant for participation. An increase in the spread between the SNB's rate and the interbank repo rate leads for 12 banks to a significantly higher probability that they will participate in the auction. Further 11 banks have the expected negative (but insignificant) sign. For the other two interest rate factors, slightly more than half of the coefficients have the expected sign but are often statistically not significant. For the FX-swap variable this is possibly due to the fact that a big majority of participating banks have actually a refinancing need in Swiss francs and not in Euro. The two banks with the significant positive coefficients are maybe long in Euro and short in Swiss franc: If the FX-swap variable rises, the implied interest rate for the Swiss franc is lower and hence refinancing from the SNB is less attractive. The coefficient on the difference between the 1-week Libor and the SNB's rate is statistically significant and positive for four banks. The probability for participation in the auction will rise if unsecured funding is less attractive compared to the funding via repo operations.

For the whole sample we conclude that the liquidity variables exhibit a strong influence on the decision to participate in the auction. Among the set of interest rate factors the relative attractiveness of the SNB's rate compared to the interbank repo rate is the most decisive variable.

\subsection{Bid amount}

Based on aggregate data an ordinary least squares (OLS) regression is run. Results are shown in the top row of table 4 . For the whole sample period, all coefficients on the influencing factors - except the one on unsecured funding - have the expected sign. If the funding from the SNB is attractive compared to the interbank market (repo, FX-swap), a bank will try to refinance a higher amount from the SNB. Numerically the spread of the SNB's rate compared to the interbank repo rate has the largest impact on the bids. An increase in the difference between the two rates $\left(i_{S N B, t}-i_{I B, t}\right)$ by one

\footnotetext{
${ }^{11}$ The 1 -week contract is settled two working days after the auction date.
} 
basis point leads to a reduction in bids of $239 \mathrm{~m}$ Swiss francs. The spread between the SNB's rate and the rate for unsecured funding exhibits the second largest (but insignificant) effect (-130 m Swiss francs), although not with the expected sign. The FX-swap variable has the smallest effect among interest rate factors $(-3.3 \mathrm{~m}$ Swiss francs per basis point). These findings can be interpreted as the repo interbank market being the most important benchmark when deciding on the amount to tender in the SNB's auction. Although all liquidity variables have the expected sign, they only partly exhibit a significant influence on the total bid amount: Solely the coefficients on yesterday's bids and banknotes in circulation are significant.

When running the regressions for the individual banks, we have to account for the nature of the dependent variable. If a bank participates in an auction, we observe its bids. If a bank does not participate in an auction, we observe a bid of zero Swiss francs. So, the bid amount is left censored at zero. To account for the censored dependent variable we employ a tobit model.

Table 4 shows the results of the tobit regressions for the individual banks. The most striking results are the highly significant coefficients on yesterday's bids and a bank's maturing repo transactions. While yesterday's bids are also significant in the regression with aggregated bids, the maturing repo operations are not. This could be because they average-out in the aggregate - and are hence captured by the constant - but are an important influencing factor when an individual bank determines its bids. Ten banks increase the tendered amount in the 1-week auction if they have more longer term repos outstanding with the SNB. For two banks the bid amount falls if they have outstanding longer term operations with the SNB. Obviously, these banks use the longer term funding as a substitute for the 1-week operations.

As we expected, the significant coefficients on the repo variable are all negatively signed. Four banks have a negative and significant coefficient on the FX-swap variable and only for one bank the coefficient is significantly positive. The coefficient for the unsecured funding is only significant and positive for one bank. For the majority of banks the coefficients, albeit insignificant, are negative. This result is counterintuitive since the participating banks usually rely on the secured and unsecured market to refinance assets. When the unsecured funding becomes less attractive, one would expect banks to shift their funding to the repo market. The costs of collateral may provide a possible explanation for the negative coefficients. As a rule of thumb, the spread between the unsecured rate and the repo rate is roughly equal to the costs of collateral. Accordingly, if the costs of collateral are high (i.e. the unsecured-repo spread high), a bank can earn a fee by lending the collateral in a securities lending transaction. Among the interest rate factors, the attractiveness of the SNB's rate compared to the repo market 
rate is the most important determinant of the bid amount. The FX-swap variable and the unsecured variable are only of minor importance.

Akin to the findings in section 5.1, the liquidity factors play a predominant role in the decision on how much to bid in the SNB's auction. Longer term operations seem not to lower the bids in the 1-week auctions in the whole sample. The spread between the SNB's rate and the prevailing rate in the interbank market is the most important interest rate factor. The FXswap variable and the unsecured funding are only of minor importance. This finding suggests that banks do not primarily use the SNB's auction to fund Euros, by obtaining the Swiss francs via repo transaction and subsequently swapping these funds into Euros via an FX-swap.

\subsection{Change in bid functions in the crisis}

Tables 3 and 5 report the changes in the bid functions in the crisis. The influence of yesterday's bids and the maturing repo transactions did not materially change in the turmoil. For few banks the changes were significant, however, no common pattern is evident. For some banks the change in the coefficient on outstanding longer term operations was significantly negative. This can be taken as sign that banks prefer longer term refinancing in order to prolong the maturity of their liabilities in the crisis: They substitute 1week for longer term repos and therefore bid less in the 1-week auctions. For the majority of banks, however, the sum of the two coefficients (whole sample plus changes in crisis) remain significantly positive, suggesting that for these banks the 1-week and longer term repos are still complements in the crisis. The fulfillment of minimum reserve requirements remains irrelevant for a large part of the banks under consideration.

For some banks the influence of the interest rate factors changed in the probit regression. For four (one) banks the change in coefficient for the repo variable was significantly negative (positive). A similar pattern is visible for the funding via FX-swap. For five (four) banks the probability of participation increases (falls), when the funding of Euros gets more (less) attractive, i.e. repo operations with the SNB and a subsequent foreign exchange swap is cheaper (more expensive) than direct funding in the Euro repo market. The unsecured funding variable is contrary to expectation. For five (one) banks the change in coefficients was significantly negative (positive). In the crisis, the funding on the unsecured market became more difficult and the interest rate difference between the unsecured and secured market increased. In this setting, one would expect that this provides higher incentives to participate in the SNB's auction. Scarcity and/or cost of collateral may have induced banks to refrain from participation in the auction. The tobit coefficients on the interest rate variables did also not materially change in the crisis. 
For four banks the coefficient on the repo variable is more negative than in the whole sample, meaning that the bid amount depends more on the attractiveness of the SNB's repo rate. Only for two banks the reaction to a change in interest rates is less pronounced than before the crisis.

The coefficients in tables 3 and 5 suggest that the banks' bidding behavior did not systematically and materially change in the money market turmoil. This result seems to be at odds with the common perception of the SNB's measures in the crisis. However, there are two reasons for this discrepancy. Firstly, the sample period covers the period up to the collapse of Lehman Brothers, i.e. the period where the crisis was relatively contained. Because the SNB's provision of reserves changed considerably after September 2008, this period was not included: Since October 2008 the SNB provides a large part of reserves through FX-swaps with the ECB, where the counterparties are not known to us. Thus the he individual banks' bidding behavior cannot be examined and as a consequence the regressions cannot be adjusted accordingly. Secondly, the 1-week auctions examined in this paper are of only minor importance for the adjustment of the supply of reserves to a change in demand. In the crisis, the banks did in fact have a volatile demand for reserves, which resulted in abrupt moves in short-term interest rates. In order to stabilize short-term interest rates, the SNB employed fine-tuning operations and thereby added or withdrew extra reserves. Fine-tuning operations are usually conducted in the overnight tenor, meaning they have an immediate effect on banks' reserves and hence on overnight rates. In contrast, term contracts like the 1-week operations are settled two working days after the auction, which renders them much less effective to address market strains. Because of these fine-tuning operations, bidding behavior in the 1-week auction was not substantially affected by the crisis. 


\section{Conclusion}

To pursue its monetary policy, the SNB uses a target range for the Swiss franc 3-month Libor as operational target. The SNB employs open market operations to govern the 3-month Libor in the target range. Its main instrument therefore are repo auctions. Among these repo auctions, the 1week tenor is by far the most frequently used term. This paper examines the banks' bidding behavior in the SNB's 1-week repo auction before and during the money market turmoil of $2007 / 2008$.

There are several rationales for a bank to participate in the auction. We divide the relevant determinants into liquidity and interest rate factors. Six liquidity factors are identified. The first are a bank's own bids in the auction of the previous day. This variable covers a bank's current refinancing need (liquidity position effect) as well as its accommodation with reserves for the next week (saturation effect). A further variable is a bank's maturing repos with the SNB. We expect this variable to exert a positive influence on the bids since a bank may want to roll-over the maturing repos. The volume of a bank's outstanding longer term repo operations with the SNB has a positive influence on bids if the SNB uses the longer term repos to partially compensate for a temporary change in autonomous factors (government balances with the SNB and banknotes in circulation). A negative effect is expected if a bank uses the longer term repos as a substitute for shorter term operations. If a bank's current average of reserves in the maintenance period is below the desired level, we expect it to have a higher incentive to participate in the auction and to bid more aggressively. The final liquidity factors are the autonomous factors. Since a rise in autonomous factors absorbs reserves from the banking system, we expect them to have a positive influence on a bank's decision to participate and on the bid amount.

The set of interest rate factors includes rates from the repo interbank market, the unsecured money market and the FX-swap market. We use the spread between the SNB's rate and the repo interbank rate as a measure of attractiveness of the SNB's rate and expect the probability of participation and the amount of bids to rise if the SNB's rate becomes more attractive relative to the market rate. Since a bank can alternatively refinance its assets in the unsecured market instead of recurring to the SNB's auction, we also include the spread between the 1-week Libor and the SNB's repo rate in the regression. If the spread between the 1-week Libor and the SNB's 1-week rate rises, we expect the bids to be higher. The last interest rate factor refers to the FX-swap. A counterparty may have a refinancing need in Euro. If it is relatively cheap to fund Euros via a repo transaction with the SNB (thereby getting Swiss francs) and to subsequently swap the Swiss francs into Euros, a bank will bid more in the auction. If a bank has excess Euros but a refinancing need in Swiss francs, it will bid less. 
For the whole sample we can conclude that among the liquidity variables yesterday's own bids and the maturing repo operations exhibit the strongest influence on the decision to participate in the auction and on the amount to bid. The two autonomous factors are of only minor importance. From the set of interest rate factors, the relative attractiveness of the SNB's rate compared to the interbank repo rate is the most important variable. The unsecured rate and the funding of Euros via FX-swaps are only significant for few banks.

The results presented in section 5 suggest that the banks' bidding behavior did not systematically and materially change in the money market turmoil of $2007 / 2008$. This finding seems to be counterintuitive at first. However, there are two reasons for this discrepancy. Firstly, the sample period only covers the period up to the collapse of Lehman Brothers, i.e. the period where the crisis was relatively contained. Secondly, the 1-week auctions examined in this paper are of only minor importance for the adjustment of the supply of reserves to a change in demand. In the crisis, the banks did in fact have a volatile demand for reserves, which resulted in abrupt moves in short-term interest rates. In order to stabilize short-term interest rates, the SNB employed fine-tuning operations and thereby added or withdrew extra reserves. Fine-tuning operations are largely conducted in the overnight tenor, meaning they have an immediate effect on banks' reserves and hence on overnight rates. In contrast, term contracts like the 1-week operations are settled two working days after the deal, which renders them much less effective to address market strains. Because of these fine-tuning operations, bidding behavior in the 1-week auction was not substantially affected.

The results of this paper suggest that the SNB's auction procedure to provide reserves to the banking system has proven useful before and during the crisis. Deviations of the interbank rate from the SNB's rate have a high impact on the bid amount. This, in turn, blurs the identification of the bank's true demand for reserves. In order to decrease the volatility of the bid amount the SNB should aim to close the spread, by providing reserves such that the interbank rate lies as near as possible to the SNB's rate. In the period of observation the spread between the two interest rates was close to zero (see table 1). This suggest that the fixed rate tender with proportional cut is a suitable tool for the management of interest rates. Alternatively, the SNB could conduct a fixed rate tender with full allotment. However, we suspect a fixed rate tender with full allotment to result in a over provision of reserves and hence a market interest rate below the SNB's rate. This is partly because banks do not have the same set of information as the central bank. Furthermore, part of the bids are not due to a refinancing need in Swiss francs but due to a demand for Euros (funding Euros via EURCHFswaps). 


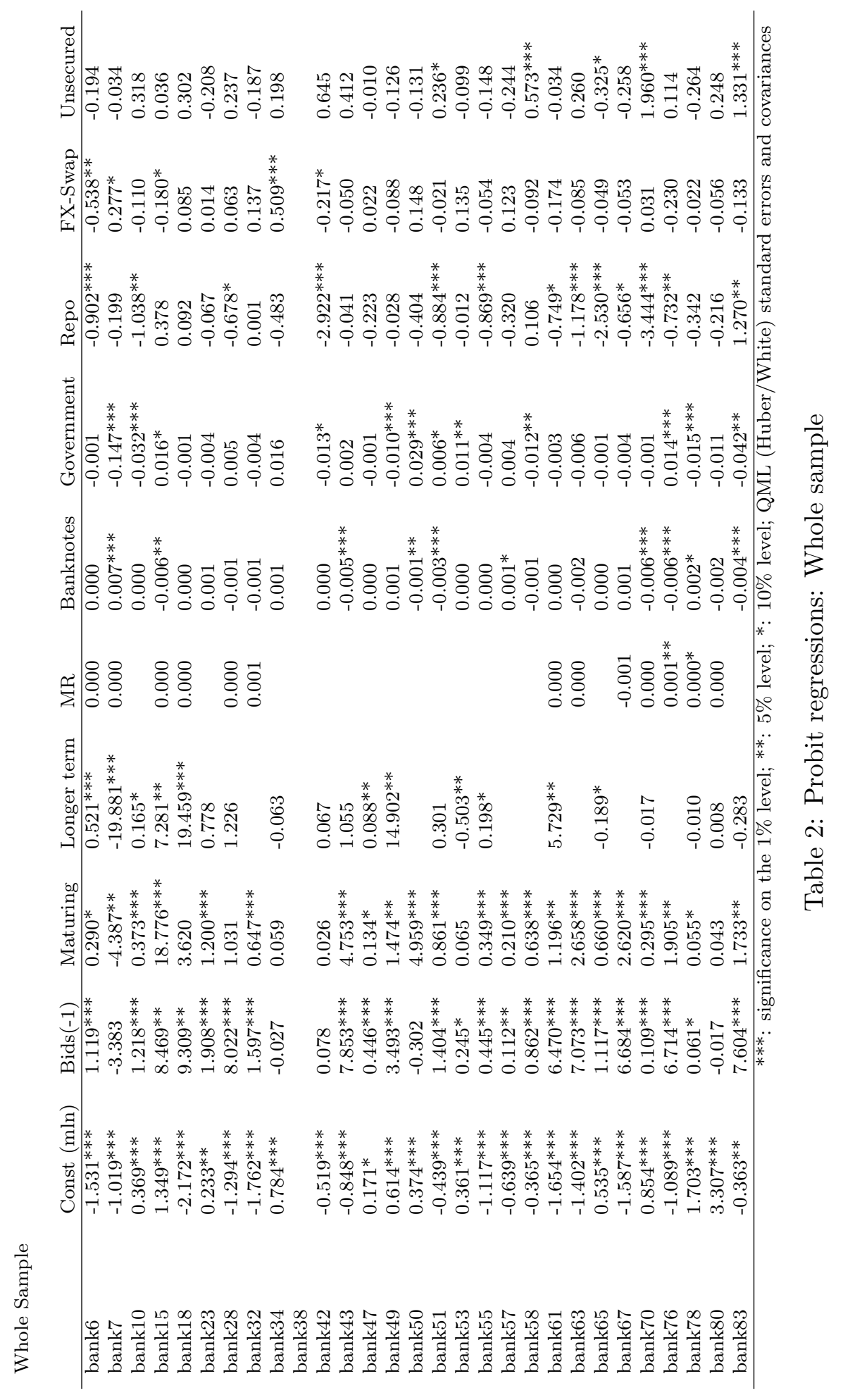




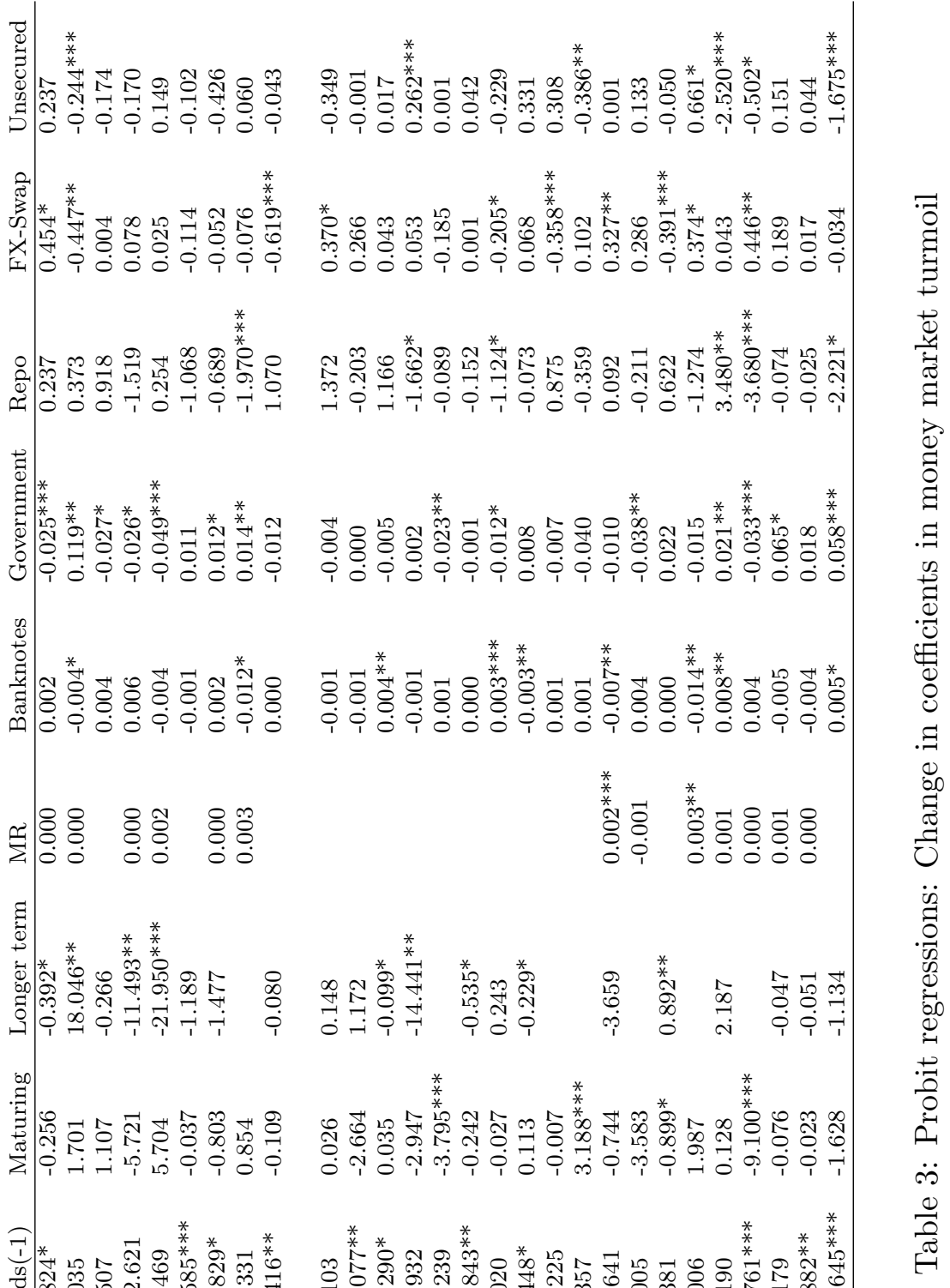

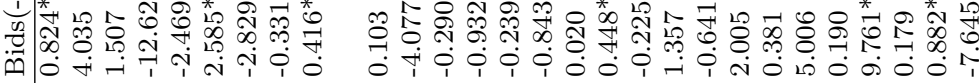
छ

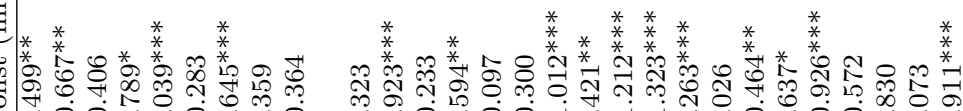
Oे

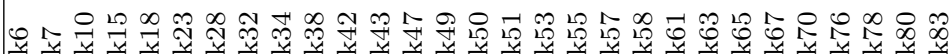




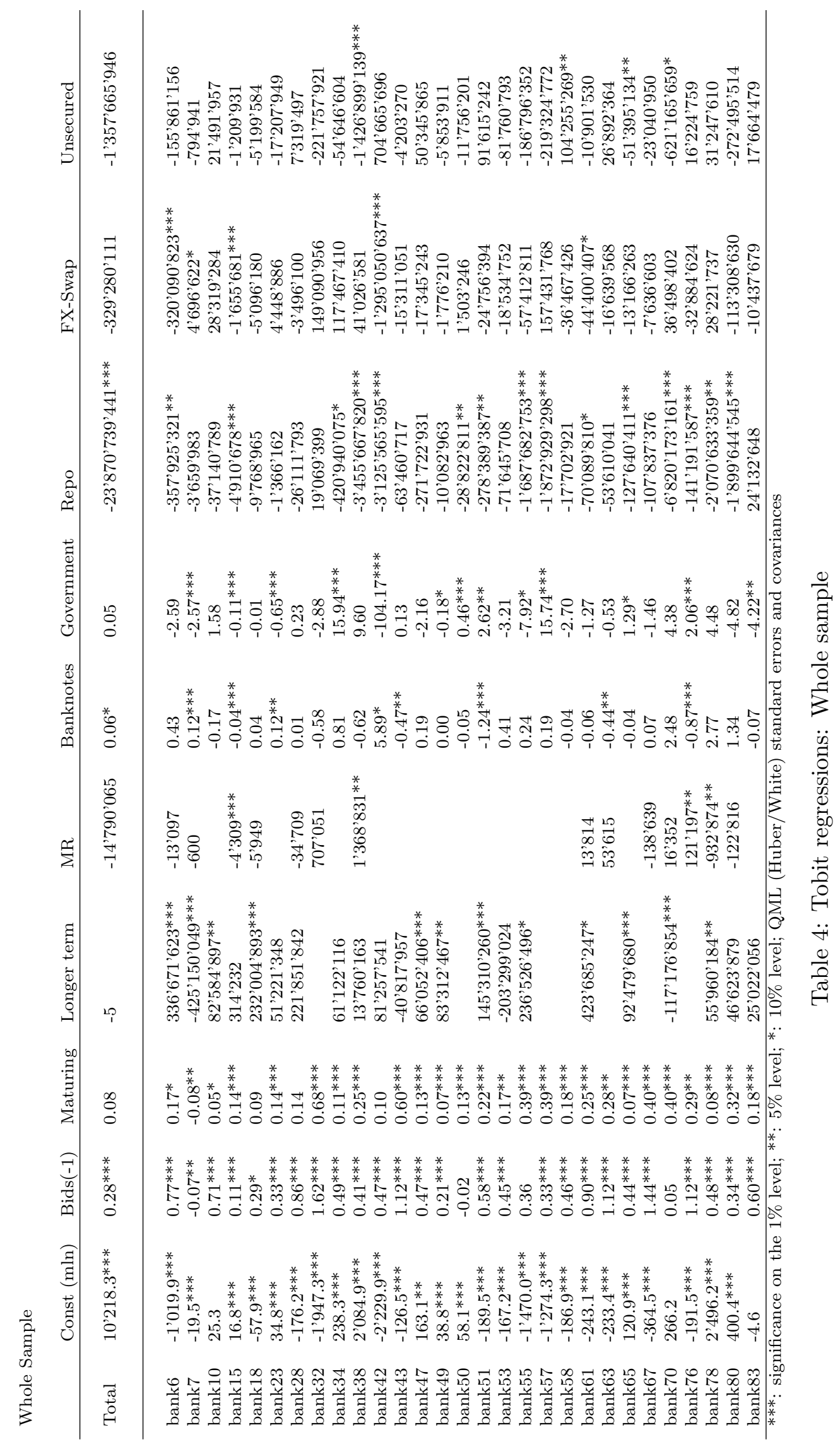




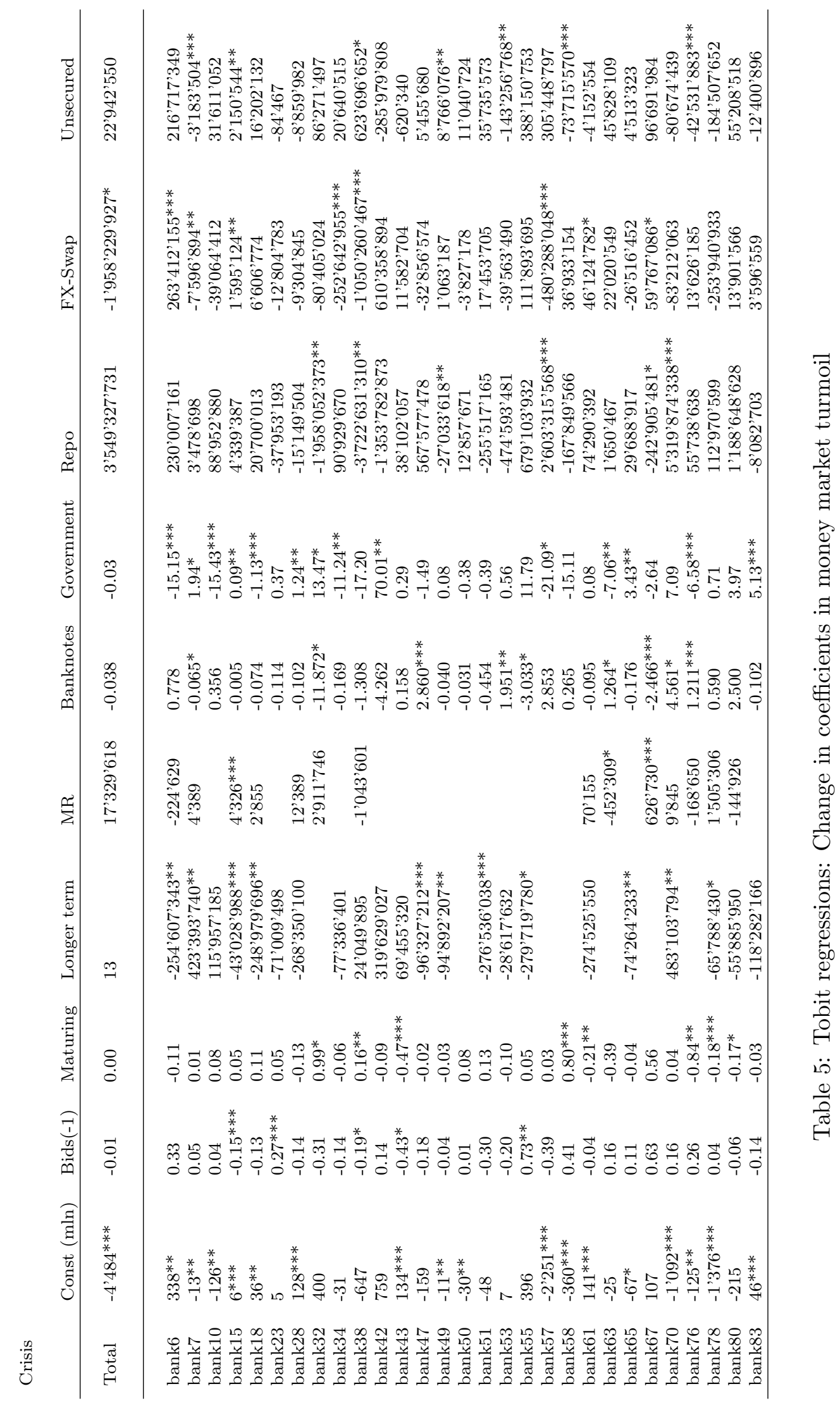




\section{References}

Baltensperger, E., Hildebrand, Ph. and Jordan, T. (2007): "The Swiss National Bank's monetary policy concept - an example of a 'principle-based' policy framework", Swiss National Bank Economic Studies No. 3.

Benito, F., A. Leon and J. Nave (2006): "Modeling the Euro Overnight Rate", WP-AD 2006-11, Working Paper Serie AD from Instituto Valenciano de Investigaciones Economicas (Ivie).

Bindseil, U. and K. Nyborg (2007): "Monetary Policy Implementation: A European Perspective", Forthcoming in, Financial Markets and Institutions: A European Perspective, Oxford University Press.

Commitee on the Global Financial System (2008): "Central Bank Operations in Response to the Financial Turmoil", CGFS Paper No 31.

Breitung, J. and D. Nautz (2001): "The Empirical Performance of the ECB's Repo Auctions: Evidence from Aggregated and Individual Bidding Data", Journal of International Money and Finance, No. 20, pp. 839-856.

European Central Bank (2000): "The Switch to Variable Rate Tenders in the Main Refinancing Operations", ECB Monthly Bulletin, July, pp. 37-42.

Ehrhart K.-M. (2000): "A Well-known Rationing Game", Sonderforschungsbereich 504, Publication 01-36, Universität Mannheim.

Ehrhart K.-M. (2001): "European Central Bank Operations: Experimental Investigation of the Fixed Rate Tender", Journal of International Money and Finance, Vol. 20, pp. 871-893.

Eisenschmidt J., A. Hirsch and T. Linzert (2009): "Bidding Behaviour in the ECB's Main Refinancing Operations During the Financial Crisis", European Central Bank Working Paper Series, No. 1052.

Jordan, T. J. and M. Peytrignet (2007): "The path to interest rate management and inflation forecasts", in The Swiss National Bank 1907-2007, pp. $255-271$.

Jordan, T. J. (2007): "Das Repo-Geschäft in Schweizerfranken und die Innovation des geldpolitischen Instrumentariums der Schweizerischen Nationalbank", Aktuelle Rechtsprobleme des Finanzplatzes Schweiz, 2007.

Jordan T. J. and P. Kugler (2004): "Implementing Swiss Monetary Policy: Steering the 3M-Libor with Repo Transactions", Schweizerische Zeitschrift für Volkswirtschaft und Statistik, Vol. 140 No. 3, pp. 381-393. 
Kraenzlin, S. (2007): "The Characteristics and Development of the Swiss Frank Repurchase Agreement Market", Financial Markets and Portfolio Management, Vol. 21, No. 2, pp. 241-261.

Linzert, T., D. Nautz and J. Breitung (2006): "Bidder Behavior in Central Bank Repo Auctions: Evidence from the Bundesbank", International Financial Markets, Institutions and Money, Volume 16, pp. 215-230.

Nautz, D. and J. Oechssler (2006): "Overbidding in Fixed Rate Tenders An Empirical Assessment of Alternative Explanations", European Economic Review, Volume 50, Issue 3, pp. 631-646.

Nautz, D. and J. Oechssler (2003): "The Repo Auctions of the European Central Bank and the Vanishing Quota Puzzle", The Scandinavian Journal of Economics, Vol. 103, Issue 2, pp. 207-220.

Swiss National Bank (2008): "Instruction Sheet on Open Market Operations", 31 December 2008. Availabe on the SNB's website.

Swiss National Bank (2004): "The Swiss National Bank in Brief", December 2004.

Swiss National Bank (1999): "Monetary policy decisions of the Swiss National Bank for 2000", Quarterly Bulletin 4/1999, pp.19-23.

Thornton, D. (2007): "Open Market Operation and the Federal Funds Rate", Federal Reserve Bank of St. Louis Review, November/December 2007, 89(6), pp. 549-70. 


\section{Swiss National Bank Working Papers published since 2004:}

2004-1 Samuel Reynard: Financial Market Participation and the Apparent Instability of Money Demand

2004-2 Urs W. Birchler and Diana Hancock: What Does the Yield on Subordinated Bank Debt Measure?

2005-1 Hasan Bakhshi, Hashmat Khan and Barbara Rudolf: The Phillips curve under state-dependent pricing

2005-2 Andreas M. Fischer: On the Inadequacy of Newswire Reports for Empirical Research on Foreign Exchange Interventions

2006-1 Andreas M. Fischer: Measuring Income Elasticity for Swiss Money Demand: What do the Cantons say about Financial Innovation?

2006-2 Charlotte Christiansen and Angelo Ranaldo: Realized Bond-Stock Correlation: Macroeconomic Announcement Effects

2006-3 Martin Brown and Christian Zehnder: Credit Reporting, Relationship Banking, and Loan Repayment

2006-4 Hansjörg Lehmann and Michael Manz: The Exposure of Swiss Banks to Macroeconomic Shocks - an Empirical Investigation

2006-5 Katrin Assenmacher-Wesche and Stefan Gerlach: Money Growth, Output Gaps and Inflation at Low and High Frequency: Spectral Estimates for Switzerland

2006-6 Marlene Amstad and Andreas M. Fischer: Time-Varying Pass-Through from Import Prices to Consumer Prices: Evidence from an Event Study with Real-Time Data

2006-7 Samuel Reynard: Money and the Great Disinflation

2006-8 Urs W. Birchler and Matteo Facchinetti: Can bank supervisors rely on market data? A critical assessment from a Swiss perspective

2006-9 Petra Gerlach-Kristen: A Two-Pillar Phillips Curve for Switzerland

2006-10 Kevin J. Fox and Mathias Zurlinden: On Understanding Sources of Growth and Output Gaps for Switzerland

2006-11 Angelo Ranaldo: Intraday Market Dynamics Around Public Information Arrivals

2007-1 Andreas M. Fischer, Gulzina Isakova and Ulan Termechikov: Do FX traders in Bishkek have similar perceptions to their London colleaques? Survev evidence of 
2007-2 Ibrahim Chowdhury and Andreas Schabert: Federal Reserve Policy viewed through a Money Supply Lens

2007-3 Angelo Ranaldo: Segmentation and Time-of-Day Patterns in Foreign Exchange Markets

2007-4 Jürg M. Blum: Why 'Basel II' May Need a Leverage Ratio Restriction

2007-5 Samuel Reynard: Maintaining Low Inflation: Money, Interest Rates, and Policy Stance

2007-6 Rina Rosenblatt-Wisch: Loss Aversion in Aggregate Macroeconomic Time Series

2007-7 Martin Brown, Maria Rueda Maurer, Tamara Pak and Nurlanbek Tynaev: Banking Sector Reform and Interest Rates in Transition Economies: Bank-Level Evidence from Kyrgyzstan

2007-8 Hans-Jürg Büttler: An Orthogonal Polynomial Approach to Estimate the Term Structure of Interest Rates

2007-9 Raphael Auer: The Colonial Origins Of Comparative Development: Comment. A Solution to the Settler Mortality Debate

2007-10 Franziska Bignasca and Enzo Rossi: Applying the Hirose-Kamada filter to Swiss data: Output gap and exchange rate pass-through estimates

2007-11 Angelo Ranaldo and Enzo Rossi: The reaction of asset markets to Swiss National Bank communication

2007-12 Lukas Burkhard and Andreas M. Fischer: Communicating Policy Options at the Zero Bound

2007-13 Katrin Assenmacher-Wesche, Stefan Gerlach, and Toshitaka Sekine: Monetary Factors and Inflation in Japan

2007-14 Jean-Marc Natal and Nicolas Stoffels: Globalization, markups and the natural rate of interest

2007-15 Martin Brown, Tullio Jappelli and Marco Pagano: Information Sharing and Credit: Firm-Level Evidence from Transition Countries

2007-16 Andreas M. Fischer, Matthias Lutz and Manuel Wälti: Who Prices Locally? Survey Evidence of Swiss Exporters

2007-17 Angelo Ranaldo and Paul Söderlind: Safe Haven Currencies 
2008-1 Martin Brown and Christian Zehnder: The Emergence of Information Sharing in Credit Markets

2008-2 Yvan Lengwiler and Carlos Lenz: Intelligible Factors for the Yield Curve

2008-3 Katrin Assenmacher-Wesche and M. Hashem Pesaran: Forecasting the Swiss Economy Using VECX* Models: An Exercise in Forecast Combination Across Models and Observation Windows

2008-4 Maria Clara Rueda Maurer: Foreign bank entry, institutional development and credit access: firm-level evidence from 22 transition countries

2008-5 Marlene Amstad and Andreas M. Fischer: Are Weekly Inflation Forecasts Informative?

2008-6 Raphael Auer and Thomas Chaney: Cost Pass Through in a Competitive Model of Pricing-to-Market

2008-7 Martin Brown, Armin Falk and Ernst Fehr: Competition and Relational Contracts: The Role of Unemployment as a Disciplinary Device

2008-8 Raphael Auer: The Colonial and Geographic Origins of Comparative Development

2008-9 Andreas M. Fischer and Angelo Ranaldo: Does FOMC News Increase Global FX Trading?

2008-10 Charlotte Christiansen and Angelo Ranaldo: Extreme Coexceedances in New EU Member States' Stock Markets

2008-11 Barbara Rudolf and Mathias Zurlinden: Measuring capital stocks and capital services in Switzerland

2008-12 Philip Sauré: How to Use Industrial Policy to Sustain Trade Agreements

2008-13 Thomas Bolli and Mathias Zurlinden: Measuring growth of labour quality and the quality-adjusted unemployment rate in Switzerland

2008-14 Samuel Reynard: What Drives the Swiss Franc?

2008-15 Daniel Kaufmann: Price-Setting Behaviour in Switzerland - Evidence from CPI Micro Data

2008-16 Katrin Assenmacher-Wesche and Stefan Gerlach: Financial Structure and the Impact of Monetary Policy on Asset Prices

2008-17 Ernst Fehr, Martin Brown and Christian Zehnder: On Reputation: A Microfoundation of Contract Enforcement and Price Rigidity 
2008-18 Raphael Auer and Andreas M. Fischer: The Effect of Low-Wage Import Competition on U.S. Inflationary Pressure

2008-19 Christian Beer, Steven Ongena and Marcel Peter: Borrowing in Foreign Currency: Austrian Households as Carry Traders

2009-1 Thomas Bolli and Mathias Zurlinden: Measurement of labor quality growth caused by unobservable characteristics

2009-2 Martin Brown, Steven Ongena and Pinar Yeșin: Foreign Currency Borrowing by Small Firms

2009-3 Matteo Bonato, Massimiliano Caporin and Angelo Ranaldo: Forecasting realized (co)variances with a block structure Wishart autoregressive model

2009-4 Paul Söderlind: Inflation Risk Premia and Survey Evidence on Macroeconomic Uncertainty

2009-5 Christian Hott: Explaining House Price Fluctuations

2009-6 Sarah M. Lein and Eva Köberl: Capacity Utilisation, Constraints and Price Adjustments under the Microscope

2009-7 Philipp Haene and Andy Sturm: Optimal Central Counterparty Risk Management

2009-8 Christian Hott: Banks and Real Estate Prices

2009-9 Terhi Jokipii and Alistair Milne: Bank Capital Buffer and Risk Adjustment Decisions

2009-10 Philip Sauré: Bounded Love of Variety and Patterns of Trade

2009-11 Nicole Allenspach: Banking and Transparency: Is More Information Always Better?

2009-12 Philip Sauré and Hosny Zoabi: Effects of Trade on Female Labor Force Participation

2009-13 Barbara Rudolf and Mathias Zurlinden: Productivity and economic growth in Switzerland 1991-2005

2009-14 Sébastien Kraenzlin and Martin Schlegel: Bidding Behavior in the SNB's Repo Auctions 
Swiss National Bank Working Papers are also available at www.snb.ch, section Publications/Research Subscriptions or individual issues can be ordered at Swiss National Bank, Fraumünsterstrasse 8, CH-8022 Zurich, fax+41 4463181 14, E-mail library@snb.ch 